\title{
Social Studies Education in Elementary Schools Through Contextual REACT- Based on Environment and Sociopreneur
}

\author{
Salati Asmahasanah*; Ibdalsyah; Maemunah Sa'diyah \\ University of Ibn Khaldun Bogor, Indonesia \\ Email: salatiasmahasanah@gmail.com \\ http://dx.doi.org/10.18415/ijmmu.v5i6.487
}

\begin{abstract}
This study aims to find out the learning profile of Social Education Science in elementary school, to know the effectiveness process through contextual of the REACT principle (Relative, Experiencing, Applying, Cooperating, And Transferring) and awareness of love environmental on Social Education Science in Elementary School, as an effort to learn innovation to improve process quality and result Learning of Social Education Science in an effort to instill a culture of love environment since primary education. The method used is qualitative descriptive, consisting of data reduction, display data, conclusion, and verification, which is done in an interactive form with data collection process as a continuous process, repeatedly, and continuously to form a cycle. This study finds that the application of environmental based contextual of the REACT principle can improve the quality of social education in elementary school as evidenced by the results of student learning increased significantly. Contextual of the REACT principle as one of the innovations in learning of Social Education Science in Elementary School able to shape the attitude of loving the environment, deepen students' understanding and develop togetherness attitude and sociopreneur (social soul and entrepreneurship). Cultural cultivation of love environment since primary education through vegetable gardening in the school yard is a meaningful learning for students.
\end{abstract}

Keywords: Contextual REACT; Environment; Social Education Science; Sociopreneur

\section{Introduction}

Efforts to promote the achievement of sustainable development goals and targets in the era of Sustainable Development Goals (SDGs) through 2030 based on the direction of the United Nations Forum which has been agreed on 2 August 2015. Improved education for Indonesians will spur achievements on other goals and objectives in 17 SDGs points, especially to improve Indonesia's human development index. So hopefully the role of education can improve the competitiveness of Indonesia in supporting the 2030 SDGs.

One of the efforts that must be done in improving the quality of education is to improve the learning system towards the better and more qualified in accordance with the goals of national education. The formulation of educational objectives contained in article 3 of Law no. 20 of 2003 on the following 
national education system: National education functions to develop the ability and form the character and civilization of a dignified nation in order to educate the nation's life, aims for the development of potential learners in order to become a man of faith and cautious to God Almighty, morals start, healthy, knowledgeable, capable, creative, independent and become a democratic and responsible citizen.

Currently, the learning model used in elementary school is more oriented to the improvement of cognitive aspect without prioritizing social and economic aspect especially in Social Science study in elementary school. The research will be aimed at finding an educational model that not only improves cognitive aspects, but also develops a culture of love for the environment and sociopreuner skills since the age of primary education that is the goal of national education.

This study of urgency is very important based on the following considerations:

1. Social Science Learning tends to be a boring subject for students;

2. The lack of innovation in the learning process in elementary school;

3. Social Science Learning in Primary School only focuses on the intelligence of cognitive alone without developing social or economic aspects;

4. The environment has not been utilized as a learning medium;

5. Culture of environmental love and Sociopreuner has not been developed in primary education;

Based on the formulation of national education objectives above, we can see a number of competencies that are expected to emerge after the education process. Competence in question is a number of abilities that can be mastered and demonstrated by students as a result of the educational process. The competence that is expected to arise as a result of the educational process referred to in the law is the development of the potential of learners to become human beings who believe and pious to God, noble, healthy, knowledgeable, capable, creative, independent and become citizens of a democratic and responsible.

In relation to that, the purpose of national education becomes a reference in the development of social science educational goals. The goals of social science that according to James Banks include a range of capabilities that include knowledge, skills in academic and think skills and value development. Competencies developed in social science include the ability to develop aspects of intellectualism and the development of social skills required by students in community life.

But the problems found by researchers in the field is the interest of learning, skills and skills of students in social science is still very minimal. The quality of the way teachers teach is also still conventional that tends to center on the teacher, so that teaching and learning activities are less attractive for students. Learning attitudes that have been implemented also not utilize the environment as a medium of learning, learners are also still focused on cognitive only without developing social and other aspects. Whereas the purpose of social science is "to foster students become good citizens, who have knowledge, skills, and social awareness that is useful for themselves as well as for society and state" while in detail oemar hamalik formulating the purpose of social science oriented on the behavior of students, those are; 1) knowledge and understanding; 2) learning attitudes; 3 ) social values and attitudes; 4) skills. 
Therefore, to solve the problem, the researcher will try an innovation of Social Science learning model that is using REACT strategy which is a contextual learning principle consisting of five elements, they are relating, experiencing, applying, cooperating cooperate), and environmental-based transferring (transferring) and sociopreuner on Social Science lessons in Elementary School. So as to improve the process and student learning outcomes. Through this learning will develop the soul of environmental love and sociopreuner since the age of primary education.

\section{Literature Study}

\section{a. Social Science Learning}

Learning is a teaching and learning activity that is any activity designed to help a person learn a new knowledge, skills, attitudes or values education Social Sciences also has a more specific purpose.

This objective is formulated by the Pennsylvania Council for the Social Studies (Clark., 1073; 8), namely: The main focus of the Social Science program is to form individuals who understand their social life - the human world, its activities and interactions aimed at generating members of society free, who have a sense of responsibility for preserving, continuing and expanding community values and ideas for future generations. To complete the objective, the Social Sciences program should focus on providing experience that will help each NCSS student (1994) specify that a good curriculum of Social Sciences education design will help build students with a view that is a blend of personal, academic pluralism and global.

Therefore, there are four perspectives that need to be developed. First personal perspective, which will help students to build their ability in investigating any events, issues and events that will impact on self, family, nation and world community. Students are expected to take into account losses and profits and accountable for every decision taken. Both academic perspectives, learning processes and experiences that students have had can be applied in student life. The various concepts he has learned can provide an understanding and choice of views about real (real) social life. The three pluralist perspectives, students can accept and appreciate the reality of community differences in terms of race, religion, gender, group and culture as a whole. Students can accept and appreciate the reality of community differences in terms of race, religion, gender, group and culture as a whole. This difference is accepted by students as a social wealth and a quality element within a democratic society. This perspective leads to multicultural education. The four global perspectives, students have a concern for the environment of the world that diminishes its natural wealth and has a commitment in dealing with a pluralistic world community.

The 2004 curriculum for Elementary School level states that, Social Knowledge (the title of Social Sciences in the 2004 curriculum), aims to:

1. Teach basic concepts of sociology, geography, economics, history, and citizenship, pedagogical, and psychological

2. Developing critical and creative thinking skills, inquiry, problem solving, and social skills

3. Building commitment and awareness of social values and humanity

4. Improving the ability to work together and compete in a pluralistic society, both nationally and globally

In line with the objective, the purpose of education of Social Sciences according to (Nursid Sumaatmadja., 2006) is "to foster students become good citizens, who have knowledge, skills, and social 
awareness that is useful for themselves as well as for society and state" While in detail Oemar Hamaling formulated the objectives of education of Social Sciences oriented toward the students' behavior, namely: 1) knowledge and understanding; 2) learning attitude; 3) social values and attitude; 4) skill (Oemar hamalik., 1992: 40-41).

\section{b. Application of Contextual Learning REACT Principle}

REACT strategy focuses on contextual learning. All of these strategies are used in the learning process. The Center for Occupational Research and Development (CORD) which contains articles in 2012 explains that the five REACT strategies are well structured and interrelated, "Relating, Experiencing, Applying, Cooperating, and Transferring ". Therefore, it can be concluded that REACT is not a sequence that must be sequentially execution but is an essential (principle) characteristic which is the five forms of learning activity structure from contextual learning. REACT is broken down into five interrelated strategies for its implementation process, and the sequence of steps is tailored to the designed learning scenario. J.R. David (in Komalasari., 2010) explains that the learning strategy is planning, still conceptual about the decisions taken in a learning implementation. Furthermore, quoting from Kemp (in Komalasari., 2010) suggests that the strategy in learning must be implemented by teachers and students so that the learning objectives can be achieved effectively and efficiently. CORD also offers guidance for educators, described as REACT strategies, which highlight the concepts behind contextual learning:

1. Related: learning in the context of life experience

2. Experiencing: learning in the context of exploration, discovery and discovery;

3. Applying: learn when knowledge is presented in the context of its use;

4. Working together: learning through the context of interpersonal communication, sharing;

5. Transferring: learning by using knowledge in a new context or situation;

Everyone can be a contextual learner but we all learn by using different learning styles.

Relating to the learning of environmental love is related to something natural phenomena that exist around us, where there is interaction between biotic factor (life) and abiotic factor (not life). The environment provides stimulus (individual stimulus) and the individual responds to the environment. In the interaction process it can happen changes in self. Another opinion about the importance of the environment as a medium of learning is similar to what Slameto says (2003: 2) "Learning is a process of doing something that a person does to gain a whole new behavioral change, as a result of his own experience in interaction with his environment".

It shows that the environment is very important influence on the acquisition of students of the lessons being studied. Education media is very important to support the achievement of educational goals. Hamalik (2004: 194) in his theory of "Back to Nature" shows how important the influence of nature on the development of learners.

Therefore, in the IPS study, this objective is formulated by the Pennsylvania Council for the Social Studies (Clark., 1073; 8), those are: The main focus of the science of social education program is to form individuals who understand their social life - the human world, its activities and interactions 
aimed at producing free, Who have a sense of responsibility for preserving, continuing and expanding community values and ideas for future generations. To complement these objectives, the science of social education program should focus on providing experiences that will help each NCSS individual student (1994) mention that the design of a good science of social education curriculum will help build students with a view that is a blend of personal, pluralist and global academics.

Accordingly, the purpose of social education science according to (Nursid Sumaatmadja, 2006) is "to foster students to be good citizens who have knowledge, skills and social awareness that are useful for themselves as well as for the society and the state." In detail, Oemar Hamalik formulates. The objectives of social education science are oriented towards the students' behavior, those are: 1) knowledge and understanding; 2) learning attitudes; 3) social values and attitudes, (4) skills (Oemar hamalik 1992: 4041).

\section{Environment}

Environment is a natural phenomenon that exists around us, where there is an interaction between the biotic factor (life) and the abiotic factor (inanimate). The environment provides stimulus (individual stimulus) and the individual responds to the environment. In the interaction process it can happen changes in self. Another opinion about the importance of the environment as a medium of learning is similar to what Slameto says (2003: 2) "Learning is a process of doing something that a person does to gain a whole new behavioral change, as a result of his own experience in interaction with his environment".

This shows that the environment is very important influence on the acquisition of students of the lessons being studied. Education media is very important to support the achievement of educational goals. Hamalik (2004: 194) in his theory "Back to Nature" shows how important the influence of nature on the development of learners. According Hamalik (2004: 195) Environment as the basis of teaching is a conditional factor that affects the behavior of individuals and is an important learning factor. The environment in question can be: Community surrounding school; Physical environment around the school, materials left or unused, used materials and when processed can be used as a source or tool in learning, as well as natural events and events that occur in society.

The general objectives of environmental education according to UNESCO in the Tbilisi (1997) conference are: 1) to help clarify issues of concern and concern about the economic, social, political, and ecological interrelationships between cities and rural areas; 2) to enable everyone to develop the knowledge, values, attitudes, commitments and abilities needed to protect and improve the environment; and 3) to create new patterns of behavior for individuals, groups and communities as a whole against environment. Objectives to be achieved include aspects: 1) knowledge; 2) attitude; 3) concern; 4) skills; and 5) participation.

Related to that, in the research results Afandi (2013) argued that the exploitation of the earth by humans impose environmental damage that threatens the habitat of humans and other living creatures on earth. through environmental education is expected to grow human conscious attitude to maintain and preserve the environment. Elementary school is a means of education in teaching environmental education is very precise, by teaching the environment awareness as early as possible to the younger generation. 


\section{d. Sociopreneur Learning}

Sociopreneur is a combination of two words, those are social and entrepreneur. In summary, Praszkier et al. (2009) defines a sociopreneur as an individual capable of making social change on a macro scale through grassroots community engagement. Martin and Osberg (in Praszkier et al., 2009) adds that sociopreneurs are different from social activists. The social change effect of a sociopreneur is long-term, stable, and profound, while social activists only struggle at the surface level.

Sociopreneurs have the potential to solve the social problems that arise in developing countries (Mustapha et al., 2008). They act as agents of social change by taking business opportunities to improve social welfare, seek innovative approaches, and disseminate their knowledge. Sociopreneur seeks to keep his business going for social values rather than pursuing profit (Brooks., 2009; Roberts \& Woods., 2005; Santos., 2009; Tan et al., 2005).

Related to that, the results of research conducted Malilang (2013) also explain that the effort that can be done is to encourage the birth of sociopreneur to improve social welfare and build the nation. One character that distinguishes between business entrepreneur and social entrepreneur is social awareness and community awareness. Some people naturally tend to have a sociopreneur character. However, these characteristics can be formed on everyone. The character in question is altruism, in which humans are essentially social beings and able to empathize. The altruistic person has five characteristics, high empathy, trust in a fair world, social responsibility, internal locus of control, and low egocentrism.

\section{Methodology}

The research method used is Qualitative Descriptive. Qualitative method is used to obtain indepth data, a data that contains meaning. The meaning is the actual data, the exact data which is a value behind the visible data. Therefore, in qualitative research more emphasis on meaning than generalization. According to the experts Lexy J. Moloeng (2004: 6) defines that qualitative research as research intends to understand the phenomenon of what is experienced by research subjects such as behavior, perception, motivation, action etc. Holistically and with descriptions in the form of words and languages in a specific, natural context and by utilizing various natural methods.

In this study, the survey is conducted on 10 primary schools located in District Lewisadeng Bogor Regency and selected as many as 4 schools in accordance with the study criteria. Those are located in remote villages, located in the mountains, but the awareness of masim farming is minimal, not utilizing the environmental media as a source of learning, especially vegetable growing media. Schools that become the location of the study are the Pamungguhan Primary School, Nego Sindangwangi Primary School, Legok Dadap Primary School and Argapuri Primary School. The total number of students are 115 students and 12 teachers.

The data source of this research is obtained from the activity of interview, observation, documentation study and FGD. The speakers of this research are students and stakeholders, those are managers of educational institutions, teachers and communities in the surrounding environment.

Methods of collecting and analyzing qualitative research data are interactive, taking place in circle overlapping. The steps are called data collection and analysis strategies, the techniques used flexibly, depending on the previous strategy used and the data already obtained (Sukmadinata., 2010: 114). Milles and Huberman (in Sangit., 2011) argue that the approach in qualitative data analysis consists of data reduction, display data, conclusions, and verification, which are conducted in an interactive form 
with the data collection process as a continuous, repeating, and continuous process to form a cycle, as shown in Figure 1.

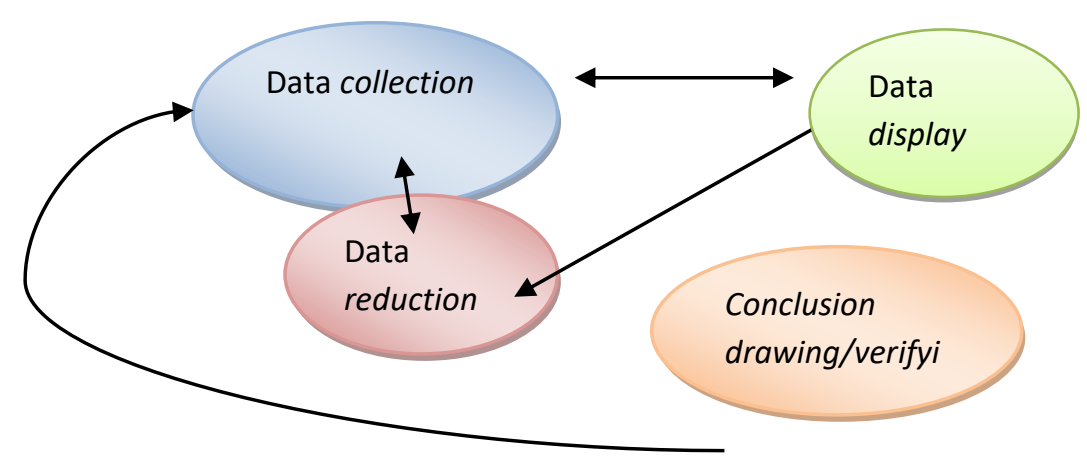

Fig. 1 Analysis of qualitative data source: Miles and Huberman

Test data validity in qualitative research include test credibility (internal validity), transferability (external validity), dependability (reliability) and conformability (objectivity).

\section{Result and Discussion}

This study finds that the application of environmental-based REACT model can improve the quality of social education in elementary school as evidenced by the results of student learning has increased significantly. REACT as one of the innovations in science of social education learning in primary school is able to shape the attitude of loving the environment, deepen students' understanding and develop togetherness attitude. Cultural cultivation of love environment since primary education through vegetable gardening in the school yard is a meaningful learning for students.

It can be concluded that the advantages of social education science learning activities with this environment-based REACT strategy are as follows:

a. Learning is more well organized and directed to each activity.

b. Grow the attitude of environmental love and sociopreneur.

c. Students can connect more learning materials through stages: Linking; Knowledge gained with daily life. Experiencing, students feel directly every learning process. Applying; Students practice and simulate according to the learning step so that more meaningful. Working together; Students work together in groups so as to train the spirit of togetherness and leadership, responsibility. Transferring: Students share their knowledge and experience in a new and useful form for others.

d. Students are trained to be courageous and confident to express something both oral and written.

e. Students are inspired in developing their potential through passion in the learning process and enthusiastic learning in the environment through the school gardens.

f. Students are more environmentally friendly and care about planted plants. 
g. Train students' skills in analyzing and evaluating the things they get.

h. To cultivate honesty and appreciate the work of others.

This is reinforced and evidenced by the statement made by Crowford (2001) that the characteristics of REACT strategy learning are deepening students' understanding, developing respect, developing togetherness and mutual understanding, developing future skills and loving the environment and making learning thorough and enjoyable.

Based on the results of the questionnaire obtained data recapitulation of teacher teaching observation results. Summarized, as follows:

a. Better student conditioning

b. The teacher starts the lesson with prayer, apperception (there are questions, icebreaking, yells and stories) then conveying the topic and learning objectives.

c. In the core activities of teaching teachers in accordance with the stages of the Implementation Plan of Learning that has been designed.

d. In the final activity, students enthusiastically give the conclusion of learning and the spirit of doing learning evaluation in the form of questions about economic and agricultural activities in the form of school gardens.

e. Learning is also done outdoor study that is directly to the school garden.

f. The activities of vegetable harvesting practices, buying and selling of vegetables are done by students enthusiastically.

g. Use of student worksheets and evaluation sheets.

h. The teacher carries out group counseling in turn.

i. Students consciously carry out pickets to care for plants by watering and cleaning them.

The percentage of development of social science learning process and result in class V (five) of all research schools is illustrated in Figure 2.

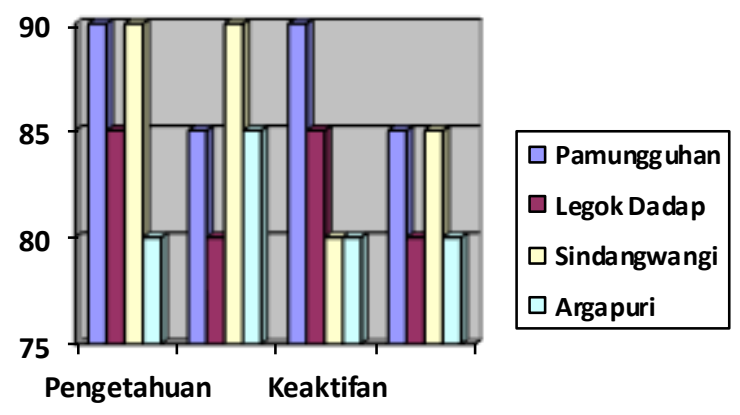

Fig. 2 Growth processes and learning outcomes 
From the average percentage of assessment aspect of knowledge of State Elementary School Pamungguhan 90, Legok Dadap 85, Sindangwangi 90 and Argapuri 80. For the aspect of the culture of environmental love attitude and sociopreneur Primary School Pamungguhan 85, Legok dadap 80, Sindangwangi 90 and Argapuri 85. In terms of the students' activity in participating in learning activities of Pamungguhan elementary school students 90, Legok dadap 85, Sindangwangi 80, Argapuri 80. And aspects of the students' skills Pamungguhan Elementary School 85, Legok dadap 80, Sindangwangi 85 and Argapuri 80. It can be concluded that the implementation REACT-based learning environment and sociopreneur can be done well.

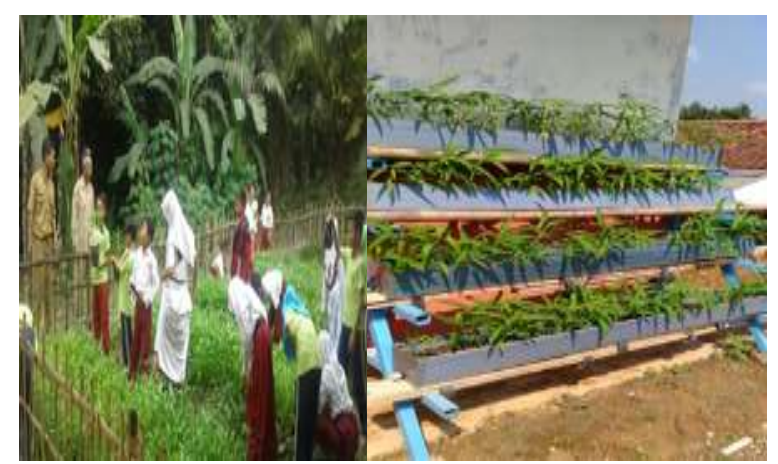

Fig. 3 School garden

\section{Conclusion}

This study finds that the application of REACT strategy based on environment and Socipreuner can improve the quality of social education in primary school as evidenced by the students' learning process has increased significantly. Contextual REACT based on environment and Socipreuner as one of innovation in learning of Social Science in elementary school able to form the attitude of loving environment, deepening students understanding, developing togetherness attitude and social spirit. Cultural cultivation of love environment since primary education through vegetable gardening in the school yard is a meaningful learning for students. The learning process and outcomes from the assessment of knowledge, attitude, liveliness and skills have also increased significantly.

\section{References}

Afandi, Rifki. (2013). Integrasi Pendidikan Lingkungan Hidup Melalui Pembelajaran IPS Di Sekolah Dasar Sebagai Alternatif Menciptakan Sekolah Hijau. Pedagogia, 2(1): halaman 98-108.

Brooks, A. C. (2009). Social Entrepreneurship: A Modern Approach to Social Venture Creation. Upper Saddle River, NJ: Pearson Education, Inc.

Cord. The REACT Strategy https://www.cord.org/the-react-learning-strategy/. Di akses 13 Februari 2016.

Crawford. (2001). Teaching contextually. Texas. CCI. Publishing. Inc.

Hamalik, Oemar. (2004). Proses Belajar Mengajar. Jakarta: Bumi Aksara

Hamalik, Oemar. (1992). Studi Ilmu Pengetahuan Sosial. Bandung: Mandar Maju. 
Komalasari, K. (2013). Pembelajaran kontekstual; konsep dan aplikasi. Bandung: Reflika Aditama Http://litbang.kemdikbud.go.id/.

Malilang CS, Andrian Liem. (2013). Penanaman Nilai dan Moral pada Anak sebagai Modal Sociopreneur Melalui Mendongeng Jurnal Entrepreneur dan Entrepreneurship, 2(1): Maret 2013.

Moleong, LJ. (2007). Metodologi Penelitian Kualitatif. Bandung: Remaja Rosdakarya.

NCSS. (1994). Expectations of Excellence: Curriculum Standards for Social Studies. Washington D.C.: Library of Congress.

Nursid Sumaatmadja. (2006). Konsep dasar IPS. Jakarta: UT.

Praszkier, R., Nowak, A. \& Zablocka-Bursa, A. (2009). Social Capital Built by Social Entrepreneurs and the Specific Personality Traits that Facilitate the Process. Psychologia Spoleczna, tom 4, 1-2 (10): 4254.

Sangit. (2011). Analisis Data Kualitatif. \{online\}. Http//:sangit26.blogspot.com.

SDGS Indonesia, http://www.sdgsindonesia.or.id/index.php/sdgs/item/182-tujuan-4-pendidikanberkualitas. Bappenas 2017.

Satori dan Komariah A. (2010). Metodologi Penelitian Kualitatif. Bandung: Alfabeta.

Sukmadinata, N.S. (2010). Metode Penelitian Pendidikan.Bandung: PT Remaja Rosda Karya.

Undang-Undang RI No. 20 Tahun 2003 tentang Sistem Pendidikan Nasional.

USAID. (2013). Kilas Balik Pendidikan di Indonesia.www.prestasi-iief.org.

\section{Copyrights}

Copyright for this article is retained by the author(s), with first publication rights granted to the journal.

This is an open-access article distributed under the terms and conditions of the Creative Commons Attribution license (http://creativecommons.org/licenses/by/4.0/). 